\title{
DIFFERENCES IN PROFESSIONAL RESPONSIBILITY FOR STATUS AND ROLE IN THE WORKPLACE
}

https://doi.org/10.37096/SHDISJ-20-1.1-0007

Sadova M.A. https://orcid.org/0000-0002-4297-7317

Podshyvalkina V.I. https://orcid.org/0000-0003-2828-5928

\begin{abstract}
The purpose of the study is to empirically substantiate the status and role differences in professional responsibility in the workplace. Methods: theoretical, empirical, mathematical statistics. Research results are based on the use of mathematical and statistical procedures, differences in the professional responsibility of workers with different status-role positions in the workplace are substantiated. These differences indicate, according to the authors, that leadership positions require greater responsibility, in contrast to the positions of subordinate personnel, since the head has the responsibility to regulate, control, organize, motivate, delegate the authority and activities of subordinates. It is shown that in comparison with subordinates, managers have a greater level of personal resources, a balance of their life achievements and failures, a higher adaptive potential and less stress vulnerability.

The presented results showed that among subordinates, but especially among managers, professional responsibility is most clearly manifested at the cognitive and behavioral levels, and to a lesser extent at the affective, emotional level.

In addition, it has been shown that managers are characterized by a significantly greater variety of socially determined career incentives, in particular, orientation to professional competence, management, autonomy, challenge, and entrepreneurship. Subordinates are more inclined to consider their work as service and are focused on the integration of various areas of their lives and on self-realization on this basis.

The results obtained suggest that the personal foundations of the subject of responsibility discovered by the authors, on the one hand, show the degree of "rooted" responsibility as a personality trait, and on the other hand, they are the most important mechanisms for the implementation of responsible human behavior in the workplace.
\end{abstract}

Keywords: professional responsibility, status-role position, ordinary employee, manager.

\section{Introduction}

The relevance of the study is due to the fact that numerous production problems in Ukraine, to some extent, are not solved due to the unfortunately widespread professional irresponsibility. Perhaps the most painful problem of today is the crisis of responsibility that permeates all structures and levels of the social organism. Irresponsible attitude of man to other people, society in general, the future of the country, the environment reaches a critical point.

The modern specialist pursues first of all his own local goals and does not want to be responsible for the consequences of his 
"SOCIALIZATION \& HUMAN DEVELOPMENT" INTERNATIONAL JOURNAL

professional activity, and even more so to take responsibility for others. Irresponsibility of employees of organizations, both management and subordinates is manifested in the long run, that is, past irresponsible actions can lead to inevitable disasters in the future.

The development of a subjective approach in psychology allows us to pay attention to the role of responsibility, in particular professional, in the development of personality. At the same time, the study of external contexts of professional activity, first of all, norms and rules of activity as conditions for freedom of choice and action in appropriate situations and formation of personal, "author's" position in relation to one's professional life acquire special significance.

The purpose of the study is to empirically substantiate the differences in the professional responsibility of specialists in terms of status and role position in the workplace.

\section{Theoretical foundations of the study}

Scientific study of this phenomenon in foreign psychology is based on a humanistic approach that explores professional responsibility: a) from a sociopsychological standpoint (W. Davis, B. Ageev, S. Anisipov, S. Buhler, M. Bakhtin, S. Baranova, O Bodalov, M. Boryshevsky, A. Brushlinsky) (Davis, 2017); b) from the standpoint of moral development of personality (E. Phares, F. Pearl, J. Piaget, L. Kohlberg, X. Heckhausen) (Phares, 1976); c) from the standpoint of personal freedom (K. Helkama, S. Kierkegaard, L. May, J. Sartre, W. Frankl, K. Jaspers) (Helkama, 2010).

In the attributive approach, responsibility and locus of control are often interpreted as synonymous concepts ( $\mathrm{J}$.
Rotter, W. Atkinson, J. Conor-Smith, D. Mcclelland, L. Murphy, R. Moss, R. Lazarus, S. Rosenzweig, J. Rotter , N. Hahn, A. Thomsen, G. Whitkin, A. Wadsworth, F. Freidenberg, S. Folkman, S. Schwartz, J. Schaefer) (Rotter, 1966).

The problem of responsibility in the psychotherapeutic approach is analyzed as a condition for the provision of psychological assistance (F. Collins, A. Bandura, O. Vepsheg, J. Sartre, W. Frankl, Z. Freud, I. Yalom) (Collins, 2013).

In the psychological and pedagogical approach the problem of education of responsibility at different age stages of formation of the person is investigated - it is a question of conditions, factors, receptions influencing education of this quality (L. Berkovitz, E. Phares, L. Slavin, V. Gorbachev, Z. Borisova, J. Zavadskaya, L. Shevchenko, I. Bekh, T. Morozkina, N. Rumyantseva, V. Semichenko) (Berkovitz, 1968).

The personal-situational approach considers professional responsibility from the standpoint of personal and situational determinants (S. Rubinstein, K. Abulkhanova-Slavska, B. Lomov, E. Klimov, J. Zavadska and L. Shevchenko) (Sadova, 2018).

The problem of professional responsibility was dealt with by Ukrainian scientists who classified a number of areas of professional responsibility research (J. Ladd, G. Lozhkin, O. Lozorko, I. Sagan, V. Pryadein, L. Dementiy, M. Koinov) (Ladd, 2015).

Unlike the above authors, our subjectcontext concept is the result of analysis and generalization of views of domestic and foreign scholars on the problem of responsibility and the author's understanding of the essence of professional responsibility in terms of 
"SOCIALIZATION \& HUMAN DEVELOPMENT" INTERNATIONAL JOURNAL

subject, object, subjectivity and context. The subject-context concept of professional responsibility allowed to identify the appropriate typology of professional responsibility of the individual, its relationship with personal and situational determinants, to make a psychological analysis of safety, risks and personal resources in the professional sphere of personal life relevant to the content of responsibility.

\section{Methods}

Subject sampling: the authors studied middle and senior managers and ordinal employees in a ratio of 1 leader to 4 subordinates. The number of people who participated in the study: leaders - 106, and subordinates - 316 people.

Methods used in the study: empirical questionnaires "Diagnosis of the level of responsibility" S. Rudenko; E. Stein's "Anchor Careers", N. Vodopyanov's "Losses and Gains of Personal Resources", M. Stein's "Level of Subjective Control" (J.C.); R. Kettell's 16-factor questionnaire; standardized interview "Components of professional responsibility" by L. Dementiy; and methods of mathematical statistics - calculations by F-test and Student's t-test.

Research procedure. Our research was conducted in several stages: an empirical research program was developed, aimed at identifying the professional responsibility of the employees of management positions and subordinates; psychodiagnostic methods were introduced, which made it possible to determine the level of responsibility of the relevant level of employees; was performed statistical data processing using the computer program SPSS 20.0 for Windows; were substantiated the results of the study.

\section{Results}

We will carry out a detailed comparative analysis of the results of tests, whuch were used for the two statuses "managers" and "subordinates".

Table 1 shows the differences between socially conditioned motivations (values, social attitudes, interests) by status and role positions (according to the questionnaire "Career Anchors". Author: E. Shane).

Analyzing the results of the table, it should be noted that significant differences in the corresponding questionnaire were found on all scales, which indicates the credibility of the results of the study. Let's analyze each of the scales of the "Career Anchor" questionnaire.

Practically at the one percent level of bilateral significance $(p \leq 0.01)$ according to the Student's t test, differences were revealed between managers and subordinates in all career settings, namely on professional competence, management, autonomy, service, challenge, integration. lifestyles, for entrepreneurship.

Table 1. Differences of socially conditioned motivations to activity (value orientations, social attitudes, interests) according to the status and role positions of employees

\begin{tabular}{|l|c|c|c|c|c|c|c|c|}
\hline $\begin{array}{c}\text { Socially } \\
\text { conditioned } \\
\text { motivations for } \\
\text { activity }\end{array}$ & $\begin{array}{c}\text { Status-role } \\
\text { position at } \\
\text { work }\end{array}$ & $\mathbf{N}$ & $\begin{array}{c}\text { Avera } \\
\text { ge }\end{array}$ & $\begin{array}{c}\text { Std. } \\
\text { deviation }\end{array}$ & $\mathbf{F}$ & $\begin{array}{c}\text { Significa } \\
\text { nce for F }\end{array}$ & $\mathbf{T}$ & $\begin{array}{c}\text { Significance } \\
\text { (2) for t }\end{array}$ \\
\hline $\begin{array}{l}\text { 1. Professionacomp } \\
\text { etence }\end{array}$ & $\begin{array}{c}\text { Managemen } \\
\text { t position }\end{array}$ & 106 & 8,0066 & 1,45034 & 6,586 &, $011^{* *}$ & 12,21 &, $000^{* * *}$ \\
\cline { 2 - 9 } & $\begin{array}{c}\text { Ordinary } \\
\text { employee }\end{array}$ & 316 & 5,8180 & 1,64238 & & & $12,99,000^{* * *}$ \\
\hline
\end{tabular}


"SOCIALIZATION \& HUMAN DEVELOPMENT" INTERNATIONAL JOURNAL

\begin{tabular}{|c|c|c|c|c|c|c|c|c|}
\hline \multirow[t]{2}{*}{ 2. Management } & \begin{tabular}{|c|} 
Managemen \\
$\mathrm{t}$ position \\
\end{tabular} & 106 & 7,6123 & 1,64639 & 6,066 &, $014 * *$ & 20,84 &, $000 * * *$ \\
\hline & \begin{tabular}{|c|} 
Ordinary \\
employee \\
\end{tabular} & 316 & 4,1563 & 1,41583 & & & 19,34 &, $000 * * *$ \\
\hline \multirow[t]{2}{*}{ 3. Autonomy } & $\begin{array}{c}\text { Managemen } \\
\text { t position }\end{array}$ & 106 & 7,1047 & 1,54120 &, 811 & ,368 & 10,91 &, $000 * * *$ \\
\hline & \begin{tabular}{|c|} 
Ordinary \\
employee
\end{tabular} & 316 & 5,2297 & 1,52711 & & & 10,86 &, $000 * * *$ \\
\hline \multirow[t]{2}{*}{ 4. Service } & $\begin{array}{c}\text { Managemen } \\
\text { t position } \\
\end{array}$ & 106 & 7,2775 & 1,32412 & 3,749 &, $054 *$ & 6,554 &, $000 * * *$ \\
\hline & \begin{tabular}{|c|} 
Ordinary \\
employee
\end{tabular} & 316 & 8,3594 & 1,51652 & & & 7,010 &, $000 * * *$ \\
\hline \multirow[t]{2}{*}{ 5. Challenge } & $\begin{array}{c}\text { Managemen } \\
\text { t position }\end{array}$ & 106 & 6,4774 & 1,54021 & ,063 & ,802 & 11,92 &, $000 * * *$ \\
\hline & \begin{tabular}{|c|} 
Ordinary \\
employee
\end{tabular} & 316 & 4,3601 & 1,59479 & & & 12,13 &, $000 * * *$ \\
\hline \multirow[t]{2}{*}{$\begin{array}{l}\text { 6. Integration of } \\
\text { lifestyles }\end{array}$} & $\begin{array}{c}\text { Managemen } \\
\mathrm{t} \text { position }\end{array}$ & 106 & 6,1829 & 1,23011 &, 513 & ,474 & 7,108 &, $000 * * *$ \\
\hline & \begin{tabular}{|c|} 
Ordinary \\
employee
\end{tabular} & 316 & 7,1302 & 1,17261 & & & 6,941 &, $000 * * *$ \\
\hline \multirow[t]{2}{*}{$\begin{array}{l}\text { 7.Entrepreneurshi } \\
\mathrm{p}\end{array}$} & \begin{tabular}{|c|} 
Managemen \\
$\mathrm{t}$ position \\
\end{tabular} & 106 & 3,6849 & 2,51198 & 18,91 & $\begin{array}{l}000 \\
* * *\end{array}$ & 2,503 &, $000 * * *$ \\
\hline & \begin{tabular}{|c|} 
Ordinary \\
employee
\end{tabular} & 316 & 3,1041 & 1,89595 & & & 2,181 &, $000 * * *$ \\
\hline
\end{tabular}

According to F-test, at one percent significance level $(\mathrm{p} \leq 0.01)$, the differences between the two groups of subjects were confirmed by such settings as the attitude to entrepreneurship and the stability of the workplace. Also by F-test, at a five percent level of significance $(\mathrm{p} \leq$ $0.05)$ were found differences in attitudes to professional competence, management, autonomy, stability of residence. In addition, according to $F$-test at a ten percent level of significance (p була 0.1) was confirmed as a trend difference in attitude to the ministry.

Let's analyze the results on scales, the significant differences between officials and subordinates are confirmed by the criteria of Student's t-test and F-test,.

According to these two criteria, the focus on professional competence is more typical for managers (8.01) than for subordinates (5.82), which is associated with their decision-making and delegation of these powers. The same applies to the installation of management. It is higher in managers (7.61) than in subordinates (4.16). For the position of manager, the attitude to management and the corresponding qualities are the key to their effective work.

Leaders (7.11) are more focused than subordinates (5.23) and on autonomy. Most likely, this is due to the need for the leader to make independent decisions, to look for adequate ways to solve problems.

In addition, career orientation as a challenge is more common in managers (6.48) than in subordinates (4.36). This indicates that managers are more inclined to solve unique problems, to implement new ideas in the work process.

To some extent, managers (3.68) are more likely than subordinates (3.10) to focus on entrepreneurship. Managers are 
"SOCIALIZATION \& HUMAN DEVELOPMENT" INTERNATIONAL JOURNAL

more independent, active, systematic in achieving economic and social results and making a profit in the organization.

At the same time, the orientation toward serving professional activities was somewhat higher among subordinates (8.36) than among managers (7.28). This may be due to their love of the profession, team or place of work.

Subordinates are also more focused on integrating their lifestyle (7.13) than managers (6.18). That is, subordinate employees, unlike managers, are more open for activities in various areas of life and the diversity of their roles.

Summarizing the above, it should be noted that it is for managers is characterized by a variety of socially determined career motivations, including the focus on professional competence, management, autonomy, challenge, entrepreneurship. Subordinates are more inclined to view their work as ministry and more focused on integrating different areas of their lives. That is, managers, more than their subordinates, are career-oriented and on a fairly wide range of social orientations.

At the next stage, we analyzed the results of the subjects with different statusrole position in the team on the questionnaire "Losses and gains of personal resources" (Authors: N. Vodopyanova, M. Stein), in order to identify the balance of their life disappointments and achievements, as a basis for the adaptive potential of the individual and his stress resilience. (See Table 2).

Table 2.Features of personal resources by status-rolepositions of employees - participants in the study

\begin{tabular}{|c|l|l|l|l|l|l|l|l|}
\hline Scales & $\begin{array}{l}\text { Status-role } \\
\text { position at } \\
\text { work }\end{array}$ & \multicolumn{1}{|c|}{$\mathbf{N}$} & $\begin{array}{c}\text { Avera } \\
\text { ge }\end{array}$ & $\begin{array}{c}\text { Std. } \\
\text { deviation }\end{array}$ & $\mathbf{F}$ & $\begin{array}{l}\text { Significanc } \\
\text { e for F }\end{array}$ & $\mathbf{T}$ & $\begin{array}{l}\text { Significan } \\
\text { ce } \\
\text { (2) for t }\end{array}$ \\
\hline 1. Staff & $\begin{array}{l}\text { Management } \\
\text { position }\end{array}$ & 106 & 1,3876 &, 4842 &, 60 &, 437 & 3,006 &, $003 * * *$ \\
\cline { 2 - 9 } \\
erdinary & 316 & 1,1997 &, 5 & & & 3,285 &, $001 * * *$ \\
\hline
\end{tabular}

The results presented in Table 2 show some differences in the average indicators of personal resources of managers and subordinates at the one percent level of bilateral significance $(\mathrm{p} \leq 0.01)$ according to Student's $t$ test and the absence of differences in variance or scattering of these indicators in the two samples by Fisher's $F$ test.

It was found that managers have a higher level of personal resources (1.39) than subordinates (1.20), which indicates a greater balance of their life disappointments and achievements, their higher adaptive potential of the personality and less vulnerability for stress.

We also performed a comparative analysis of the results of the test-interview "Components of professional responsibility" (Author: LI Dementiy) of employees with different status and role positions in the workplace. (See Table 3). 
"SOCIALIZATION \& HUMAN DEVELOPMENT" INTERNATIONAL JOURNAL

Table 3. Differences in the components of professional responsibility

for the status and role positions of employees

\begin{tabular}{|c|c|c|c|c|c|c|c|c|}
\hline Components & $\begin{array}{c}\text { Status-role } \\
\text { position at } \\
\text { work }\end{array}$ & $\mathbf{N}$ & Average & $\begin{array}{c}\text { Std. } \\
\text { Deviation }\end{array}$ & $\mathbf{F}$ & $\begin{array}{c}\text { Significance } \\
\text { for F }\end{array}$ & $\mathbf{T}$ & $\begin{array}{c}\text { Significance } \\
\text { (2) for t }\end{array}$ \\
\hline 1. Cognitive & $\begin{array}{c}\text { Management } \\
\text { position }\end{array}$ & 106 & 8,745 & 2,51873 & 24,204 &, $000 * * *$ & 6,702 &, $000 * * *$ \\
\cline { 2 - 9 } & $\begin{array}{c}\text { Ordinary } \\
\text { employee }\end{array}$ & 316 & 7,215 & 1,84422 & & & 5,758 &, $000 * * *$ \\
\hline 2. Behavioral & $\begin{array}{c}\text { Management } \\
\text { position }\end{array}$ & 106 & 9,226 & 2,63776 & 10,282 &, $001 * * *$ & 6,352 &, $000 * * *$ \\
\cline { 2 - 9 } & $\begin{array}{c}\text { Ordinary } \\
\text { employee }\end{array}$ & 316 & 7,541 & 2,26531 & & & 5,890 &, $000 * * *$ \\
\hline
\end{tabular}

Statistical analysis of the test-interview results showed that of the three components of professional responsibility: behavioral, cognitive (evaluative-reflexive) and emotional at the one percent level of bilateral significance $(\mathrm{p} \leq 0.01)$ according to the Student's $t$ - test and at the one percent level of significance $\leq 0.01$ ) according to Fisher's F test, differences between managers and subordinates were found only in the behavioral and cognitive components. It is important to emphasize that both managers and subordinates tend to both show professional responsibility in their behavior and reflect and evaluate it, although it is managers who have higher scores on these two components than subordinates (respectively 9.23 vs. 7.54, and 8.75 vs. 7.22). There were no differences in the affective component of professional responsibility of managers and subordinates.

At the next stage of our study, we analyzed the results of respondents who participated in our study on the questionnaire "Subjective Control" (Author: J. Rotter), as in previous cases, dividing them by status-role position of study participants. (See Table 4).

Table 4. Features of subjective control over the status and role positions of employees participating in the study

\begin{tabular}{|c|c|c|c|c|c|c|c|c|}
\hline Scales & $\begin{array}{c}\text { Status-role } \\
\text { position at } \\
\text { work } \\
\end{array}$ & $\mathbf{N}$ & $\begin{array}{l}\text { Avera } \\
\text { ge }\end{array}$ & $\begin{array}{c}\text { Std. } \\
\text { deviation }\end{array}$ & $\mathbf{F}$ & $\begin{array}{l}\text { Significa } \\
\text { nce for } F\end{array}$ & $\mathbf{T}$ & $\begin{array}{l}\text { Significance } \\
\text { (2) for } t\end{array}$ \\
\hline \multirow{2}{*}{$\begin{array}{l}\text { 1. The scale of } \\
\text { general } \\
\text { internality }\end{array}$} & \begin{tabular}{|c|} 
Managemen \\
t position \\
\end{tabular} & 106 & 36,38 & 4,57024 & ,229 & ,633 & 12,908 &, $000 * * *$ \\
\hline & \begin{tabular}{|c|} 
Ordinary \\
employee
\end{tabular} & 316 & 29,58 & 4,73511 & & & 13,138 &, $000 * * *$ \\
\hline \multirow{2}{*}{$\begin{array}{l}\text { 2. The scale of } \\
\text { internality in the } \\
\text { field of } \\
\text { achievement }\end{array}$} & $\begin{array}{c}\text { Managemen } \\
\mathrm{t} \text { position }\end{array}$ & 106 & 9,943 & 1,43978 & 2,665 & ,103 & 13,619 &, $000 * * *$ \\
\hline & $\begin{array}{l}\text { Ordinary } \\
\text { employee }\end{array}$ & 316 & 7,905 & 1,29609 & & & 12,925 &, $000 * * *$ \\
\hline \multirow{2}{*}{$\begin{array}{l}\text { 3. Scale of } \\
\text { internality in } \\
\text { family relations }\end{array}$} & $\begin{array}{c}\text { Managemen } \\
\text { t position }\end{array}$ & 106 & 6,227 & 1,69105 & 10,67 &, $001 * * *$ & 7,391 &, $000 * * *$ \\
\hline & $\begin{array}{l}\text { Ordinary } \\
\text { employee }\end{array}$ & 316 & 7,452 & 1,39795 & & & 6,727 &, $000 * * *$ \\
\hline
\end{tabular}


"SOCIALIZATION \& HUMAN DEVELOPMENT" INTERNATIONAL JOURNAL

\begin{tabular}{|l|l|l|l|l|l|l|l|l|}
\hline $\begin{array}{l}4 . \quad \text { Scale of } \\
\text { internality in }\end{array}$ & $\begin{array}{c}\text { Managemen } \\
\text { t position }\end{array}$ & 106 & 3,254 &, 74401 &, 076 &, 783 & 6,897 &, $000 * * *$ \\
$\begin{array}{l}\text { the field of } \\
\text { interpersonal } \\
\text { relations }\end{array}$ & $\begin{array}{l}\text { Ordinary } \\
\text { employee }\end{array}$ & 316 & 2,686 &, 73026 & & 6,833 &, $000 * * *$ \\
\hline
\end{tabular}

As we can see from Table 4, the largest differences in the mean (Student's t test) and variance (Fisher's F test) between the two status-role positions were found on the scale of internality in the family relationships of the subjects. That is, subordinates are more involved in family processes and control them more than managers.

In addition, significant differences were found between the average values of the two subgroups (according to Student's t test) on the scales of general internality, internality in interpersonal relations, in the situation of achievements, in the field of health and disease. Indicators of internality in the field of failures differ in two subgroups at the five percent level $(\mathrm{p} \leq$ $0,05)$ according to Student's t-test.

We also analyze according to table 4 the average value of these scales. Such indicators on the scale of general internality in managers (36.39) are at the highest level, nor in subordinates (29.59). Thus, managers have higher subjective control over any significant situations. According to the psychological content of the scale, managers believe that most important events in their lives were the result of their own actions, that they can control them and, therefore, take responsibility for their lives in general to a greater extent than subordinates.

The average results on the scale of internality in the field of achievement also dominate in managers (9.94), compared with subordinates (7.91). This suggests that managers on this scale have a higher level of subjective control over emotionally positive events than subordinates. Leaders believe that all the best in their lives they have achieved themselves and that they are able to successfully go to the goal in the future.

On a scale of internality in family relations (at subordinates - 7,45, at heads of the organizations $-6,23$ ), subordinates on the average consider themselves more responsible for the events occurring in their family life unlike heads who are focused mainly on punishment.

As for the scale of internality in the field of interpersonal relations, this figure of the heads of organizations is higher than that of subordinates (3.25 vs. 2.69). This indicates that managers feel able to evoke the respect and sympathy of others, and subordinates are not entirely inclined to take responsibility for their relationships with others.

Thus, based on the analysis of the data of the questionnaire "Subjective control" we can conclude that the level of internal control in different situations is more pronounced in the heads of organizations than in subordinates, except for situations of family relations.

At the next stage of our study, we analyzed the development of the level of employee responsibility for the "Responsibility Questionnaire". S. Rudenko, dividing them by status-role position (See Table 5). 
"SOCIALIZATION \& HUMAN DEVELOPMENT" INTERNATIONAL JOURNAL

Table 5. Differences in the level of responsibility of managers and ordinary employees who participated in the study

\begin{tabular}{|c|c|c|c|c|c|c|c|c|}
\hline Scales & $\begin{array}{l}\text { Status-role } \\
\text { position at } \\
\text { work }\end{array}$ & $\mathbf{N}$ & $\begin{array}{c}\text { Averag } \\
\text { e }\end{array}$ & $\begin{array}{l}\text { Std. } \\
\text { deviati } \\
\text { on }\end{array}$ & $\mathbf{F}$ & $\begin{array}{c}\text { Significanc } \\
\text { e for } F\end{array}$ & $\mathbf{T}$ & $\begin{array}{l}\text { Significanc } \\
e \\
\text { (2) for } t\end{array}$ \\
\hline \multirow{2}{*}{$\begin{array}{l}\text { Level of } \\
\text { responsibi } \\
\text { lity }\end{array}$} & $\begin{array}{c}\text { Management } \\
\text { position }\end{array}$ & 106 & 54,9245 & 3,29125 & 9,615 &, $002 * * *$ & 16,01 &, $000 * * *$ \\
\hline & $\begin{array}{l}\text { Ordinary } \\
\text { employee }\end{array}$ & 316 & 47,2342 & 4,56163 & & & 18,76 &, $000 * * *$ \\
\hline
\end{tabular}

With regard to the level of professional responsibility of managers and subordinates, based on the analysis of the results presented in table 5 , it can be stated that at the one percent level of bilateral significance $(\mathrm{p} \leq 0.01)$ the differences between the mean values of the two subsamples Significance $(p \leq 0.01)$ of differences in the variances of the two subsamples according to Fisher's F test revealed a higher level of responsibility in managers (54.92 vs. 47.23 subordinates).
This suggests that generally executives more responsible, because they are responsible not only for themselves, for their own actions and deeds, but also for other persons who are their subordinates.

At the next stage of the empirical study, we suggested that the safe and risky type of professional responsibility of the leader directly depends on the style of leadership. This hypothesis was confirmed empirically, and the results of its research are presented in table 6 .

Table 6. Features of leadership style with safe and dangerous types of professional responsibility of the individual

\begin{tabular}{|c|c|c|}
\hline \multirow[t]{2}{*}{ Leadership style } & \multicolumn{2}{|c|}{ Types of professional responsibility of the individual } \\
\hline & Safe type & Dangerous type \\
\hline Authoritarian & $78,39 * *$ & 51,92 \\
\hline Democratic & 56,41 & $89,49 * * *$ \\
\hline
\end{tabular}

(Note: $* * *-p \leq 0.001 ; * *-p \leq 0.01 ; *-p \leq 0.05$ according to the F-Fisher criterion).

Based on the analysis of Table 6, we see that the safe type of professional responsibility is characterized by a predominantly authoritarian leadership style (78.39), and to a lesser extent liberal (60.52) and democratic (56.41). We explain the results of the study by the fact that in an authoritarian style of management, managers seek and try to subdue subordinate staff. Such leader alone determines the activities of subordinates, regulates their every step, suppresses any initiative of the specialists he manages. The dominant means of influence of such a leader (orders, instructions, orders, instructions, strict control, inhibition of creative efforts) lead to the fact that he does not take responsibility, but on the contrary in a rigid form transfers it to his subordinates.

The risky type of professional responsibility is characterized by a more democratic style of leadership (89.49), and less authoritarian (51.92) and liberal (31.25). In conditions of risk, the manager assumes part of the responsibility and solves complex and risk-related problems collectively.

The liberal style of leadership (the role of mediator), according to our research, is 
"SOCIALIZATION \& HUMAN DEVELOPMENT" INTERNATIONAL JOURNAL

not dominant in any of the types of professional responsibility.

\section{Discussion}

Theoretical and methodological analysis of the phenomenon of professional responsibility allows us to record the existence of several scientific theories and approaches to the study of the structure of professional responsibility of the individual, namely as a three-component (L. Dementiy, A. Spirkin, VF Safin, TN Sidorova, M. Svitinnia), as a factor (AP Pryadein, A. Perlin), as a functional (K. Muzdybaeva). Such a diversity of scientific vision has led to the fact that in some theories, responsibility has been interpreted rather narrowly, fragmentarily (reduction of responsibility only to its cognitive component), and in others - extremely broad.

Thus, today there are no common views on the structure of professional responsibility. The problem of external form of responsibility as acceptance of necessity became a priority in many researches (MV Mukonin, TY Bazarov, VA Bodrov, CB Bykov, AL Zhuravlyov, AB Karpov, RL Krichevsky, Yu. P. Platonoa, AL Sventsitsky). In our opinion, in research in this field, the essence of unpredictable and conflict situations as contexts of professional responsibility of the subject remains practically outside the scientific interest.

From the point of view of the authors of the article, professional responsibility of the individual can be considered as a higher and integrative professionally significant education of the individual, which reflects (or determines) the scope and quality of strategic self-control of the subject and ensures the organization of professional activity. and meeting the needs of other people (clients) in content, results and consequences of work.

Important points that have not been highlighted by other researchers in defining the phenomenon of professional responsibility is that we consider professional responsibility:

- first as a professionally significant education of a specialist, which characterizes the productive performance of professional tasks and due to creative initiative and a high level of professional self-actualization;

- secondly, through the prism of the specialist's ability to strategic self-control, which covers a long period of his activity and is associated with ways to achieve a complex goal in the performance of professional duties and tasks;

- thirdly, we study not only the content but also the consequences of the results of work, which testify to both professional responsibility and professional irresponsibility of the subject of labor

The scientific and methodological novelty of the presented study is that the subject-context approach proposed by the authors of the article is based on the idea that each subject of professional activity (specialist, manager) is forced to relate in some way to the context of external reality (to norms and rules of professional production, to the requirements of a particular place of work), while deserving of freedom of choice and action in appropriate situations. He also has the opportunity to develop personal professional responsibility in order to exercise this freedom properly. The problem is how much the subject is able to anticipate the consequences of their actions in the context of professional activities and 
be responsible for them, to make independent life and professional choices and be the "author" of his life, to understand himself as a responsible person.

From the point of view of subjectcontext approach, we connect professional responsibility with personal qualities of a specialist, his freedom of choice, independence, with individual uniqueness, efficiency, humanity, locus of control, motivation to achieve, level of demands and personal resources in overcoming difficulties. Within the framework of this approach in the study of professional responsibility there are two forms objective and subjective, which can be in different, including contradictory, combinations. Responsibility in any professional field combines the fact that it is a form of control over the activities of the subject at its various stages and characterizes the responsibility from the standpoint of the micro-society (team), or individual (specialist). The personal bases of the subject of responsibility revealed by us, on the one hand, show the degree of "rootedness" of responsibility in the person, on the other - are the most important mechanisms of realization of responsible behavior at a workplace. Integrating with these personal mechanisms, responsibility acts as the most important regulator of the subject's behavior in the context of unforeseen circumstances and risk situations (situational determinants) in the workplace. Optimally responsible person increases measure of own personal responsibility in situations that, on the one hand, are significant, difficult, non-standard and personally controlled, and on the other contain the possibility of choice, leadership, risk.
To date, there are debatable issues regarding the differences between the components of professional responsibility of urban and rural residents; national and regional features of professional responsibility; possibility of influence on the professional responsibility of the individual of his / her confessional affiliation, level of education, work experience in the specialty.

\section{Conclusion}

Professional responsibility is understood by the authors as a higher and integrative professionally significant education of the individual, which reflects the scope and quality of strategic selfcontrol of the subject and ensures the organization of professional activities (and colleagues), taking into account respect, interest and satisfaction of other people (clients). in the results and consequences of work.

Differences in the professional responsibility of employees with different status and role positions in the workplace, which were identified using mathematical and statistical procedures, indicate that:

1) managerial positions require more responsibility, in contrast to the positions of subordinate staff. The leader has the responsibility to regulate, control, organize, motivate, delegate authority and activities of subordinates, and this implies that they have leadership skills that must not only have, but also improve in the process of professional activity;

2) in comparison with subordinates, managers have a higher level of personal resources, which indicates a balance of their life disappointments and achievements, a higher adaptive potential and less stress vulnerability. Significant advantages of managers (in average values) 
were identified in cognitive and behavioral components of professional responsibility;

3) managers are characterized by a much greater variety of socially motivated career motivations, in particular, the focus on professional competence, management, autonomy, challenge, entrepreneurship. Subordinates are more inclined to view their work as ministry and are focused on the integration of various spheres of their lives and on self-realization on this basis.

The personal bases of the subject of responsibility revealed by us, on the one hand, show the degree of "rootedness" of responsibility as property of the person, on the other - act as the most important mechanisms of realization of responsible behavior of the person at a workplace.

\section{References}

Berkovitz L. (1968). The Traditionally socialy responsible personality. N.Y. : Public Opinion Quartely. 323.

Collins F. (2013). The Spesial Responsibility of Engeneers. The Social Responsibility of Engeneers. Annals of the New York Academy of Sciences. Vol. 196 (10), 55-68.

Davis W. L. (2017). Internal-external control and attribution of responsibility for success and failure. Journal of personality. 40, 123-136.

Helkama K. (2010). Toward a cognitiviedevelopmental theory of attribution of responsibility. Helsinki, 220 .

Ladd J. (2015). Philosophical Remarks and Professional Responsibility in Organizations. Applied Philosophy. Vol. 1 (2), 45-50.

Phares E. J. (1976). Locus of Control in Personality, Morristown. N. J. : General Learning Press. 217.

Rotter J. B. (1966). Generalized expectancies for internal versus external locus of control of reinforcement: Psychological Monographs Text. 328.

Sadova M. A. (2018). Psykholohichni skladovi profesiinoi vidpovidalnosti osobystosti [Psychological components of professional responsibility]. Odessa : Vydavets Bukaiev Vadym [in Ukrainian].

Sadova M.A. (2018). Empirical structure of professional responsibility of personality by factor analysis. Innovative solutions in modern science. Dubai, №6 (25), 112-122. 